\title{
Knowledge of I nternet-using patients about the perioperative period of orthognathic surgery
}

\author{
Bruna do Rego Barros, Cristina Silva Sousa, Ruth Natalia Teresa Turrini \\ School of Nursing, University of São Paulo, Brazil \\ Correspondence: Cristina Silva Sousa. Address: Rua Professora Carolina Ribeiro, 20 ap 54 Vila Mariana, São Paulo - CEP \\ 04116020. Brazil. Telephone: 55-119-9601-7972. Email: crissousa@usp.br.
}

Received: January 27, 2013

Accepted: March 14, 2013

Online Published: May 21, 2013

DOI : $10.5430 /$ jnep.v3n12p93

URL: http://dx.doi.org/10.5430/jnep.v3n12p93

\begin{abstract}
Background: Identify the knowledge and information needs of Internet-using patients undergoing orthognathic surgery by blogs and virtual communities.

Methods: Exploratory descriptive study that obtained the data from virtual communities and blogs of Portuguese language not administrated by surgeons or treatment clinics. Thematic content analysis was used to identify the comments of interest and it was identified 257 posts that fit the study's objective.

Results: The data were separated in two groups: pre and post-operatory period. The most common topics were related to recovery, paresthesia, costs, edema, fear, and outcome. Other problems, such as pain, eating, anesthesia, regret, mouth opening, kissing, doubt, laser therapy, voice changes, procedures, counsel, difficulty breathing, acne, orthodontics, relief, faith, physical therapy, medical licensure, hair loss, and acupuncture, were also discussed.

Conclusions: Based on this analysis, we concluded that principal information needs of internet-using patients are related to the recovery of the masticatory functions and reducing the edema and paresthesia. A good professional-patient bond can help patients to clarify their doubts and avoid the use of Internet to solve their postoperative difficulties.
\end{abstract}

\section{Key words}

Orthognathic surgery, Internet, Perioperative period, Health knowledge, Attitudes, Practice

\section{I ntroduction}

Orthognathic surgery is a type of dental treatment in adults that includes maxillofacial surgery and orthodontics to create a normal facial pattern in patients with facial disharmonies ${ }^{[1]}$. Although this procedure has been used for only a few decades, it has proven to be very effective. In addition to their functional and aesthetic effects, facial structural disharmonies also affect the patient psychologically and socially ${ }^{[2]}$.

Patience is an important requirement for orthognathic surgery because orthodontic preparation takes approximately one and a half years. In addition, the recovery period after surgery is variable, and the physical appearance of the face may worsen. However, the main concern for patients is the obscurity of information, especially related to the problems inherent to the surgery. Because this is a drawn-out procedure with a complicated recovery, it is very important that patients are well instructed from the time they decide to have the surgery ${ }^{[3]}$. 
The physicians focus upon teaching the patients about the technical aspects of the procedures and the clinical results, rather than the psychological and social impact of the surgery. Patients prefer attention to the matters that concern them regarding the upcoming surgery rather than the technical aspects ${ }^{[4]}$. In recent years, as hospital stays have become shorter, the responsibilities of nurses for the outcomes of their postoperative instructions have increased ${ }^{[5]}$.

Nurses often use oral communication to interact with patients. Teaching skills, proficient knowledge of the applicable subject, and scheduling that allows the professional to take time for this activity are necessary to be successful ${ }^{[3]}$. However, despite all of the means of communication available such as virtual environments, especially blogs, these forms of communication indicate that patients have not had their information needs met by their health team.

People are increasingly using the Internet to share experiences and exchange information. The number of people who use the Internet to find health information increases every year worldwide, as observed in a study developed in the United States ${ }^{[6]}$.

A study of the "health diary" on a virtual blog showed that the day-to-day experiences of post-operative recovery helped patients better understand treatment options. This information may provide patients with realistic expectations for the post-operative recovery and improve how information is transmitted to the patient ${ }^{[7]}$.

Even with the many interactions through the Internet by patients seeking knowledge regarding their particular surgery or illness, the Internet has consequences for lack of clarity of information. Patients can find incorrect information on surgical care, resulting in their problem not solved or worsened. One study confirmed that a considerable number of people search for health information on the Internet and change their behavior and treatment choices based on the information they find. These users may misunderstand this information and may be overly confident in its accuracy ${ }^{[8]}$.

Therefore, the goal of the present study was to identify the informational needs of Internet-using patients undergoing orthognathic surgery by analyzing the concerns and experiences expressed on the Internet. This information can provide tools for nurses responsible for perioperative education, promote faster recovery, and minimize patient suffering.

It should be clarified that the data shown in this paper are part of one of the steps of a project to create a perioperative booklet for patients who undergo orthognathic surgery ${ }^{[9]}$, approved by the Ethics Committee of the São Paulo University School of Nursing (Protocol number: 972/2010).

\section{Subjects and methods}

This exploratory descriptive study used data from virtual environments. The search engine Google ${ }^{\circledR}$, which accounts for almost $72 \%$ of all Internet searches ${ }^{[6]}$, was used for searches. The sites Yahoo ${ }^{\circledR}$, Orkut ${ }^{\circledR}$, and blogs, were chosen based on their popularity.

The inclusion criteria during this study were as follows: virtual communities and blogs not administered by surgeons or treatment clinics, and in Portuguese language. Comments related to doubts, expectations or concerns on orthognathic surgeries were included, but those related to recommendations or personal opinions were excluded.

The keyword "orthognathic surgery" was used to filter the communities. The time for which the community had existed was not considered. Data collection spanned from January to June 2011. All the comments related to perioperative care of orthognathic surgery identified in the virtual communities or blogs were considered for the study and coded by the following numbers to protect the blogger: Blog 1, Blog 2, Blog 3, Blog 4, and Blog 5.

A thematic content analysis as described by Bardin ${ }^{[10]}$ was applied to the collected information. This method encompasses a group of research techniques that attempt to find the meanings of a document by examining the significant attributes of 
the research subject. This method consists of three phases. First, the text is read superficially. Second, analysis units are selected (marked sections are clipped) for deep content analysis. Third, the clippings are categorized (identified elements are classified and similar ones grouped) ${ }^{[11]}$.

Three researchers individually read the comments repeatedly to identify the main topics. The topics defined by each researcher were compared and discussed to get a consensus and then categories were established. The data obtained were separated in two groups: preoperative period and postoperative period, each of them with its specific categories.

\section{Results}

The authors identified 257 posts on orthognathic surgery, including questions about pre and postoperative procedures. By reading the posts, the topics were quantified and divided into preoperative and postoperative concerns, with 68 and 182 posts in each group, respectively. Seven posts belonged to both categories.

The greatest concern expressed by Internet users was related to recovery $(n=48,19.2 \%)$, followed by paresthesia $(n=43$, $17.2 \%)$, costs $(n=40,16.0 \%)$, and edema $(n=33,13.2 \%)$. Other subjects comprised $34.4 \%(n=86)$ of the posts.

The data analysis brought about the following thematic categories: preoperative period (costs, return to daily activities, anesthesia); postoperative period (immediate and near-term postoperative period, eating and oral hygiene, paresthesia, respiration, acne and hair loss, edema; pain, voice changes, self-image).

\subsection{Preoperative period}

Before surgery, patients were more concerned about anesthesia and the economic aspects of the procedure than the postoperative discomfort or care.

\section{Costs}

Cost was one of the most frequent themes. The posts showed that patients are unaware of how much of the service is covered by either the governmental Unified Health System (Sistema Único de Saúde - SUS) or private health insurances, as indicated by the following phrases:

"I would like to know if orthognathic surgery is performed through SUS? And how to proceed if it is?" (Yahoo)

“Is orthognathic surgery covered by any health insurance?” (Yahoo)

\section{Returning to daily activities}

Some people were worried about how long it would take to return to their daily activities, as indicated:

"And how is it after the operation, since I work and I need to know if I will need to miss many days. I already researched it [...], and of course I don't plan on going to work with pain and/or a swollen face."(Blog4)

"How long until I can leave home, go to work, I work directly with people this is my main concern, I am married and what about my household responsibilities? " (Blog5)

\section{Anesthesia}

Concerns about anesthesia were related to fear, as seen here:

“Can I die from the anesthesia used in orthognathic surgery?” (Yahoo)

“My greatest fear is the general anesthesia. I am afraid I won't wake up.” (Blog4) 


\subsection{Postoperative period}

After the surgery, the patient is faced with the impacts and limitations resulting from the procedure in terms of their nutritional, hygienic, comfort, social, and emotional needs.

\section{I mmediate and near-term postoperative period}

Questions about recovery were the most common, and the posts addressed the difficulty of the first few days after the surgery. Some of the concerns included feeling out of breath, difficulties sleeping, and problems with oral function:

"It has been 3 days. I report that I have not been able to sleep yet. During the first night in the hospital, I couldn't breathe right, as my nose was clogged with blood. During the 2nd night I had terrible pain in my ear and my head did not hurt, but it throbbed and I heard a hammer banging near my ear (...) it felt like my tongue was blocking the back of my mouth at one point and was suffocating me." (Blog4)

"But the first few days were terrible and I was often short of breath, I had insomnia and some hot flashes (which apparently are due to one of the medications)." (Blog3)

\section{Eating and oral hygiene}

During postoperative recovery, mouth opening, especially for eating and oral hygiene, bothered some patients. On the Internet, patients shared their challenges and how they overcame them:

"Brushing my teeth is still very difficult. I know that it’s gross, but I squirted water in my mouth with a syringe and let gravity drain it back out” (Blog4)

Problems with mouth opening after surgery may be linked to the complexity of the surgery, as some procedures require greater manipulation of the compromised areas. We frequently found passages that sought help. For example,

"I am unable to open my mouth more than one finger width; can you teach me exercises that you did at home?" (Blog5)

Eating was also mentioned as a concern, including what foods, textures, and food temperatures were allowed.

“(...) On eating, can you send me recipes, please? Have you lost much weight? Can you drink açaí? At first was it hot or cold liquid?” (Blog1)

“(...), do you remember how long you were on liquids?? Was it only liquids or were you able to eat soft foods or something similar??” (Blog4)

\section{Paresthesia}

Paresthesia was the second most common issue addressed by patients. The following sentences show the anxiety caused by this issue, despite the technical terms adopted to evaluate the intensity of the event:

"And my paresthesia? It was a class II, it has been one and a half months and I can't feel my chin or my lower lip very well. I am worried..." (Orkut)

"So for me, my worries got even worse, because not only do I have paresthesia that messes everything up, I don't feel like I am prettier than before the surgery.” (Blog5)

“(...) Another thing I noticed was how I was drooling and couldn’t spit.” (Blog4) 
In addition to the nuisance of paresthesia, several people asked about laser therapy, acupuncture, or physical therapy as a solution:

"I heard that acupuncture and laser sessions help. Can you guys tell me about it...?” (Blog5)

"I would just like to know what exercises you did in physical therapy and how often? Were they grimaces?" (Blog5)

\section{Respiration}

The effects of skeletal relocation on the air passages of the pharynx are rarely considered:

“All day long, I had the sensation that I couldn't breathe correctly." (Orkut)

"The first day was the DARKEST. I was not feeling pain, but was always short of breath (...) I thought I was going to die...” (Blog1)

\section{Acne and hair loss}

Some people also suffered from acne and hair loss after surgery:

"I got a chin, but now I am full of zits and almost bald. Bad luck... somebody know what it is??” (Orkut)

\section{Edema}

The posts also show that people were not well informed about edema and the time that it could last, making them impatient:

"My problem is that I have a face that is $4 x$ bigger than normal, I am all swollen and I have a cut on my lips." (Blog4)

"It will have been 3 months (since my surgery) on 4/20 and I feel very frustrated because I am still swollen!" (Orkut)

\section{Pain}

The number of individuals who felt pain during postoperative recovery was not significant, perhaps because they used anti-inflammatory drugs to reduce edema, but it was a concern for some:

"I did not feel any pain in my face, but I felt a strong pain in my left ear during the first few days, but it soon passed.” (Blog5)

Ear pain was probably due to the temporomandibular articulation.

\section{Voice changes}

Several people were worried about voice changes:

"I noticed that my voice changed a little and my diction worsened, I have been told that I am a little nasal, did this happen to you?” (Blog5)

\section{Self image}

Patients are very anxious about the results and want to have a better appearance; however, they are unsure of how long this will take: 
"One of the things I keep thinking about is whether people will still recognize me after the surgery, did you change much???” (Blog2)

"I know that it took awhile for me to recognize myself in the mirror." (Blog5)

“How long more or less did it take to appear 'normal'?” (Orkut)

\section{Discussion}

The awareness of the adversities experienced by orthognathic surgery patients is vital for the perioperative nursing assistance, in such a way that their real needs for information be supplied and the stress and anxiety reduced. Thus, as in other cosmetics surgery there is always concerns related to the coverage of the surgery by health insurance.

In Brazil, orthognathic surgery is included in the governmental coverage list of procedures only to patients with labiopalatal or cranial-facial lesions. Some health insurance offers coverage of surgery, but the release process is lengthy. When the patient uses own resources, the costs for the surgery are high. In United Kingdom the total treatment costs, including both orthodontics and surgery, were calculated for 352 subjects and the average cost for the tax year from 2001 was $€$ $6293,72$ (from $€ 3796,66$ to $€ 12010,03)^{[12]}$.

The role of the nurse is especially important during the preoperative period to decrease the patient's anxiety and to guide them as they search for answers about the procedure's coverage by SUS or other health insurance policies.

The patients were worried about the anesthesia. The fear of the unknown is the principal cause of preoperative patients' insecurity and anxiety, with concerns frequently centering on anesthesia and recovery ${ }^{[13]}$ as well as fear of staying awake during the surgery. The chances of being conscious during surgery are between one and two cases per one thousand ${ }^{[14]}$. To avoid negative preoperative experiences, anesthesiologists perform pre-anesthetic visits to evaluate the patient and to administer sedatives if necessary ${ }^{[15]}$.

Although the research considered only Internet-using patients, their major postoperative concerns were similar to those revealed by patients during a focal group that discussed the postoperative stage of orthognathic surgery. In this Brazilian study the patients mentioned the experience with paresthesia, month opening, edema, oral hygiene, loss sensibility, longer time for recovery and self-image ${ }^{[16]}$.

During the postoperative period, patients' can feel discomfort/pain and medication use persists for two to three weeks. In general, patients were able to return to their daily activities, except for sports. However, problems with oral function, such as chewing and brushing teeth, remained for approximately six to eight weeks ${ }^{[7]}$.

The patients mentioned difficulties with eating and oral hygiene. In a study of patients undergoing orthognathic surgery for temporomandibular dysfunction, only $26.3 \%$ of patients said that they had problems opening their mouth ${ }^{[17]}$, but only a third of the patients had been contacted.

Some patients asked for exercises to improve recovering. Physical therapy exercises without medical clearance or without monitoring by a professional physical therapist can hinder the patient's recovery, especially when instruction is provided without visually demonstrating how to do the movement.

After surgery, patients had to follow a diet because of the limitation of some movements to open the mouth and they can get bothered and loose weight with that. At first, the patient's diet consists of only liquids. If they have difficulties adapting, intervention by a nutritionist is necessary to prevent too much weight loss. A study evaluating the impact of a 
high-calorie liquid supplement to prevent or minimize the catabolism linked to the surgery compared to ingestion of liquefied food concluded that adding the supplement to their diet helps patients maintain their preoperative weight ${ }^{[18]}$.

Suggesting recipes or cooking techniques to prepare a food more flavorful may help the patient during the liquid diet phase when the monotony of the foods' consistency can discourage the patient from ingesting a sufficient amount of calories daily. Not uncommonly, obese or overweight patients see this time as an opportunity to loose weight.

The Internet-using patients indicated the paresthesia as an unpleasant experienced adversity. Paresthesia is a sensitivity disorder that, in orthognathic surgery, results from peripheral nerve damage. The sensation includes stinging, itching, or tingling, which can give the impression of hardening skin ${ }^{[19]}$.

A study on orthognathic surgery patients showed that $83.0 \%$ of them presented some feeling of altered facial sensation, with $55.7 \%$ experiencing changes in the chin and $27.3 \%$ in the lips. These complications decreased within one to six months after surgery. The authors concluded that altered sensation may develop after orthognathic surgery as an inevitable complication, but this condition can resolve spontaneously over time ${ }^{[20]}$.

Integrative medicine may help patient deal with paresthesia better and decrease the length of time required for functional rehabilitation of the masticatory musculature. Laser therapy has shown promising results as a nerve regeneration therapy. It can have therapeutic effects on biological systems by promoting temporary analgesia, regulating inflammatory processes, or modulating cellular responses ${ }^{[19]}$. Sensorial retraining exercises performed at home, under the direction of a physical therapist, may diminish the duration of paresthesia. A study comparing two groups, one that performed these exercises and another that did only mouth opening exercises, showed that the former group experienced 2.2 times less paresthesia than the latter ${ }^{[21]}$. Acupuncture is also useful for treating sensorial paralysis, and the result is better when the treatment is started early ${ }^{[22]}$.

Difficulty breathing related to changes in the dimension of the airways were demonstrated after surgical repositioning of the maxilla and mandible, possibly resulting in changes in the facial skeletal anatomy and respiratory disruption during sleep ${ }^{[23]}$. Intermaxillary fixation, although commonly used in orthognathic surgery to establish the occlusion, may inhibit the upper airways, affecting the patient's respiration. In cases with bad alignment and bad occlusion in which the patient keeps their mouth open and breathes through it, intermaxillary fixation may interfere with the upper airways and result in poor breathing after surgery with general anesthesia. Additionally, swelling of the tongue and other soft tissues can decrease the open area in the oral cavity and increase air resistance, making breathing even more difficult ${ }^{[24]}$.

The voice changes are possible because surgical procedures that alter the oral cavity, such as orthognathic surgery, may also affect the tongue's position or function ${ }^{[25]}$. A speech therapy evaluation can detect oral myofunctional changes that could compromise the orthodontic and orthognathic surgery results ${ }^{[26]}$.

Few Internet-using patients were worried about acne and hair loss. This complication is rare and occurs in less than $1.0 \%$ of healthy patients that receive 30 hours of intravenous steroids after orthognathic surgery ${ }^{[27]}$. A study on patients who underwent orthognathic surgery found a low incidence $(0.6 \%)$ of postoperative acne ${ }^{[28]}$.

Alopecia generally occurs in an area limited to the occipital region after surgery. Its cause may be linked to prolonged ischemia of the hair follicles, resulting from constant pressure due to incorrect positioning of the patient during surgery. Hypotension may also have some influence on alopecia. Hair loss is normally temporary, with growth returning in one to three months. Postoperative alopecia can be avoided by positioning the patient's head adequately and changing their position during the procedure to avoid prolonged pressure on the same area ${ }^{[29]}$. Because position changes can't be implemented during orthognathic surgery, it is recommended that the necessary protective measures, such as a pyramidal cushion on the surgical table, be used. 
The temporary edema on the lips and cheeks is a normal reaction that is usually intensified between 24 and 72 hours following the surgery; during the surgery significant changes in the soft tissue occur. A study on patients undergoing orthognathic surgery showed that the average edema volume decreases approximately $60.0 \%$ one month after surgery and that facial morphology regresses approximately $83.0 \%$ by the end of three months ${ }^{[30]}$. This effect can be reduced with anti-inflammatory drugs and enzyme preparations such as serrapeptase. Other methods such as lymphatic drainage, cryotherapy, and soft laser are also used. The therapeutic use of cold temperatures is beneficial for treating edema, pain, and inflammation, in addition to reducing bleeding and bruises, as the activity of inflammatory enzymes is lower at low temperatures ${ }^{[31]}$.

Pain was rarely mentioned. The study on sensorial retraining did not observe any impact on pain during postoperative recovery. This was attributed to the low proportion of patients who feel pain during the first three months and the low incidence of neuropathic complications after orthognathic surgery ${ }^{[21]}$. In many cases, orthognathic surgery is also effective in decreasing other types of pain, such as cervicobraquial pain and headaches ${ }^{[32]}$.

Changes in body image are common among patients. Ignoring such aspects can lead to dissatisfaction with the outcome of the surgery and frustration not only for the patient but also for the surgeon, indicating the need for patient counseling before surgery. Since a disharmonic facial profile can be potentially destructive psychologically and socially, it can influence the patient's self-esteem and their interpersonal relationships ${ }^{[33]}$. Therefore, the instructions given to patients should be adequate, honest, and clear to increase the patient's confidence level. In this manner, the patient will know exactly what will happen after surgery and will be better prepared for it psychologically.

The analysis of the content of Internet-using patients' statements revealed the emotional component underlying the physical concerns and the expectation about results achieved that begin in the preoperative stage of the surgery. The way the patients expressed themselves through writing also revealed the emotional burden experienced by them during the perioperative period.

Although the findings of this research met its purpose, the search only included virtual communities in Portuguese language; perhaps the Internet-users in other countries could contribute with more information's about the own needs of patients undergone to orthognathic surgery.

\section{Conclusion}

The main information needs of Internet-using patients about orthognathic surgery are related to the recovery of the masticatory functions and reducing the edema and paresthesia. Another important aspect of the postoperatory period is the outcome of the surgery involving the body image and self-esteem.

The connection between the patient and the professional is of upmost importance to ensure that the client feels free to express their doubts. It is the responsibility of the professional to show that they are accessible and interested. If not, the patient will look for support and comfort in virtual communities, where they may not always find accurate information.

The communication in these virtual communities allowed the authors to perceive feelings related to temporary physical and functional changes that are not always perceived in a group of patient education.

Nurses can diminish preoperative concerns during the preoperative visit, the ideal moment to reduce patient anxiety about the anesthetic/surgical procedure. They play an important role as an educator through spoken or written communication about concerns regarding the postoperative recovery period. Due to the long recovery period, a booklet about perioperative care can help patients to better deal with it. 


\section{References}

[1] Laureano Filho JR, Silva EDO, Vasconcellos RJH, Silva LCF, Rocha NS. Alterações estéticas em discrepâncias ânteroposteriores na cirurgia ortognática. Rev Cir Taumatol Buco-maxilo-fac. 2005; 5: 45-52.

[2] Coutinho TA, Abath MB, Campos GJL, Antunes AA, Carvalho RWF. Adaptações do sistema estomatognático em indivíduos com desproporções maxilo-mandibulares: revisão da literatura. Rev Soc Bras Fonoaudiol. 2009; 14: 275-9. http://dx.doi.org/10.1590/S1516-80342009000200021

[3] Paula AAD, Carvalho EC. Ensino sobre perioperatório a pacientes: estudo comparativo de recursos audiovisual (vídeo) e oral. Rev Latino-Am Enfermagem. 1997; 5: 35-42. PMid:9370765 http://dx.doi.org/10.1590/S0104-11691997000300006

[4] Williams RW, Travess HC, Williams AC. Patients' experiences after undergoing orthognathic surgery at NHS hospitals in the south west of England. Br J Oral Maxillofac Surg. 2004; 42: 419-31. PMid:15336767 http://dx.doi.org/10.1016/j.bjoms.2004.05.008

[5] Friedlander MR, Lage OC. O acompanhamento do paciente pós cirúrgico por meio da visita domiciliária. Acta Paul Enferm. 2003; 16: 49-55.

[6] Aldairy T, Laverick S, McIntyre GT. Orthognathic surgery: is patient information on the Internet valid? Eur J Orthod. 2012; 34: 466-9. PMid:21459834 http://dx.doi.org/10.1093/ejo/cjr046

[7] Phillips C, Blakey G, 3rd, Jaskolka M. Recovery after orthognathic surgery: short-term health-related quality of life outcomes. J Oral Maxillofac Surg. 2008; 66: 2110-5. PMid:18848110 http://dx.doi.org/10.1016/j.joms.2008.06.080

[8] Siliquini R, Ceruti M, Lovato E, Bert F, Bruno S, De Vito E, et al. Surfing the internet for health information: an italian survey on use and population choices. BMC Med Inform Decis Mak. 2011; 11: 21. PMid:21470435 http://dx.doi.org/10.1186/1472-6947-11-21

[9] Sousa CS, Turrini RNT. Creating and Validating Educational Material for Patients Undergoing Orthognathic Surgery. Asian Nursing Research. 2012; 6: 166-72. http://dx.doi.org/10.1016/j.anr.2012.10.006

[10] Bardin L. Análise de conteúdo. Portugal: Edições 70; 2009.

[11] Campos CJG. Método de análise de conteúdo: ferramenta para a análise de dados qualitativos no campo da saúde. Rev Bras Enferm. 2004; 57: 611-4. PMid:15997809 http://dx.doi.org/10.1590/S0034-71672004000500019

[12] Kumar S, Williams AC, Ireland AJ, Sandy JR. Orthognathic cases: what are the surgical costs? Eur J Orthod. 2008; 30: 31-9. PMid:17962313 http://dx.doi.org/10.1093/ejo/cjm086

[13] Fighera J, Viero EV. Vivências do paciente com relação ao procedimento cirúrgico: fantasias e sentimentos mais presentes Rev SBPH. 2005; 8: 51-63.

[14] Bischoff P, Rundshagen I. Awareness under general anesthesia. Dtsch Arztebl Int. 2011; 108: 1-7. PMid:21285993

[15] Kim WS, Byeon GJ, Song BJ, Lee HJ. Availability of preoperative anxiety scale as a predictive factor for hemodynamic changes during induction of anesthesia. Korean J Anesthesiol. 2010; 58(4): 328-33. PMid:20508787 http://dx.doi.org/10.4097/kjae.2010.58.4.328

[16] Santos MRM, Sousa CS, Turrini RNT. Perception of orthognathic surgery patients on postoperative care. Rev Esc Enferm USP. 2012; 46: 78-85. PMid:23250262 http://dx.doi.org/10.1590/S0080-62342012000700012

[17] Dujoncquoy JP, Ferri J, Raoul G, Kleinheinz J. Temporomandibular joint dysfunction and orthognathic surgery: a retrospective study. Head Face Med. 2010; 6: 27. PMid:21083902 http://dx.doi.org/10.1186/1746-160X-6-27

[18] Kendell BD, Fonseca RJ, Lee M. Postoperative nutritional supplementation for the orthognathic surgery patient. J Oral Maxillofac Surg. 1982; 40: 205-13. http://dx.doi.org/10.1016/0278-2391(82)90312-3

[19] Farias B. Parestesia do nervo alveolar inferior após cirurgia dos terceiros molares mandibulares. Monografia. Paraiba: Universidade Federal da Paraíba; 2010.

[20] Kim YK, Kim SG, Kim JH. Altered sensation after orthognathic surgery. J Oral Maxillofac Surg. 2011; 69: 893-8. PMid:21211888 http://dx.doi.org/10.1016/j.joms.2010.10.025

[21] Phillips C, Kim SH, Essick G, Tucker M, Turvey TA. Sensory retraining after orthognathic surgery: effect on patient report of altered sensations. Am J Orthod Dentofacial Orthop. 2009; 136: 788-94. PMid:19962601 http://dx.doi.org/10.1016/j.ajodo.2008.07.015

[22] Ka L, Hirata Y, Kobayashi A, Wake H, Kino K, Amagasa T. [Treatment results of acupuncture in inferior alveolar and lingual nerves sensory paralysis after oral surgery]. Kokubyo Gakkai Zasshi. 2006; 73: 40-6. PMid:16629469 http://dx.doi.org/10.5357/koubyou.73.40

[23] Turnbull NR, Battagel JM. The effects of orthognathic surgery on pharyngeal airway dimensions and quality of sleep. J Orthod. 2000; 27: 235-47. PMid:11099556 
[24] Yamaguchi H. Effects of intermaxillary fixation during orthognathic surgery on respiratory function after general anesthesia. Anesth Prog. 2001; 48: 125-9. PMid:11724220

[25] Niemeyer T. Cirurgia ortognática produção e fala. [dissertação] Bauru: Hospital de Anomalias Craniofaciais - Universidade de São Paulo; 2004.

[26] Pacheco V. Cirurgia ortognática: uma abordagem fonoaudiológica. Rev Cefac. 2000; 2: 38-44.

[27] Fung MA, Berger TG. A prospective study of acute-onset steroid acne associated with administration of intravenous corticosteroids. Dermatology. 2000; 200: 43-4. http://dx.doi.org/10.1159/000018314

[28] Precious DS, Hoffman CD, Miller R. Steroid acne after orthognathic surgery. Oral Surg Oral Med Oral Pathol. $1992 ; 74: 279-81$. http://dx.doi.org/10.1016/0030-4220(92)90058-X

[29] Lypka MA, Yamashita DD, Urata MM. Postoperative alopecia following orthognathic surgery. J Oral Maxillofac Surg. 2008; 66: 1957-8. PMid:18718409 http://dx.doi.org/10.1016/j.joms.2008.04.014

[30] Kau CH, Cronin AJ, Richmond S. A three-dimensional evaluation of postoperative swelling following orthognathic surgery at 6 months. Plast Reconstr Surg. 2007; 119: 2192-9. PMid:17519721 http://dx.doi.org/10.1097/01.prs.0000260707.99001.79

[31] Rana M, Gellrich NC, Joos U, Piffko J, Kater W. 3D evaluation of postoperative swelling using two different cooling methods following orthognathic surgery: a randomised observer blind prospective pilot study. Int J Oral Maxillofac Surg. 2011; 40: 690-6. PMid:21411291 http://dx.doi.org/10.1016/j.ijom.2011.02.015

[32] Corbacelli A, Cutilli T, Marinangeli F, Ciccozzi A, Corbacelli C, Necozione S, et al. Cervical pain and headache in patients with facial asymmetries: the effect of orthognathic surgical correction. Minerva Anestesiol. 2007; 73: 281-9. PMid:17380104

[33] Nicodemo D, Pereira MD, Ferreira LM. Cirurgia ortognática: abordagem psicossocial em pacientes Classe III de Angle submetidos à correção cirúrgica da deformidade dentofacial. R Dental Press Ortodon Ortop Facial. 2007; 12: 46-54. http://dx.doi.org/10.1590/S1415-54192007000500007 